\title{
tanum \\ Beta-Glucan in Foods and Health Benefits
}

\author{
Seiichiro Aoe $\mathbb{B}$
}

check for

updates

Citation: Aoe, S. Beta-Glucan in

Foods and Health Benefits. Nutrients 2022, 14, 96. https://doi.org/ $10.3390 /$ nu14010096

Received: 30 November 2021

Accepted: 16 December 2021

Published: 27 December 2021

Publisher's Note: MDPI stays neutral with regard to jurisdictional claims in published maps and institutional affiliations.

Copyright: (C) 2021 by the author. Licensee MDPI, Basel, Switzerland. This article is an open access article distributed under the terms and conditions of the Creative Commons Attribution (CC BY) license (https:// creativecommons.org/licenses/by/ $4.0 /)$.
The Institute of Human Culture Studies, Otsuma Women's University, Chiyoda-ku, Tokyo 102-8357, Japan; s-aoe@otsuma.ac.jp

Many articles and manuscripts focusing on the structure, function, mechanism of action, and effects of $\beta$-glucan have been published recently. Beta-glucan is a general term for polysaccharides that consist of $\beta$-bonds. Structural studies report that combinations of $\beta-1,3$ and $\beta-1,6$ bonds form long linear $\beta$-glucans, and these structures can be detected by specific intestinal receptors, such as dectin-1, which then stimulate the immunological system [1]. Cereal $\beta$-glucans that have been derived from barley and oats have also been widely researched in both animal and human studies [2-5]. They are water soluble, viscous polysaccharides with a linear structure in which glucose is bound through $\beta-1,4$ and $\beta-$ 1,3 linkages. Many physiological functions, such as anti-obesity effects, reductions in postprandial glucose increases, and the normalization of serum cholesterol levels have been reported [6,7]. The recent interest in barley and oat $\beta$-glucans has been sparked by reports discussing their prebiotic action, which is dependent on molecular weight [8,9]. A marketing report discussing the health benefits of the $\beta$-glucans in oats and barley products has also been published [10]. Another $\beta$-glucan that has been recently reported on is paramylon, a linear $\beta-1,3$-glucan in which glucose is $\beta-1,3$ bound and that is abundant in Euglena gracilis. It is an insoluble and unfermentable polysaccharide which is reported to have various physiological functions, including anti-obesity effects and anti-diabetic effects, and has been shown to stimulate immune function [11,12].

This Special Issue entitled " $\beta$-glucan in foods and health benefits" reports on the health benefits of indigestible carbohydrates with respect to metabolic diseases and immune functions. The effects of $\beta$-glucan have been investigated through the use isolated preparations or natural dietary fibers from whole grain cereals and brans, yeasts, or Euglena. This Special Issue includes original research articles that are based on human intervention studies that address the effects of $\beta$-glucan on metabolic diseases and immune function-related markers as well as in vitro and in vivo studies. It also reviews the health benefits of $\beta$-glucans in humans.

Funding: This research received no external funding.

Conflicts of Interest: The author declares no conflict of interest. 


\section{References}

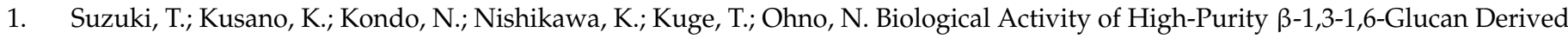
from the Black Yeast Aureobasidium Pullulans: A Literature Review. Nutrients 2021, 13, 242. [CrossRef] [PubMed]

2. Wolever, T.M.S.; Mattila, N.; Rosa-Sibakov, N.; Tosh, S.M.; Jenkins, A.L.; Ezatagha, A.; Duss, R.; Steinert, R.E. Effect of Varying Molecular Weight of Oat $\beta$-Glucan Taken just before Eating on Postprandial Glycemic Response in Healthy Huma. Nutrients 2020, 12, 2275. [CrossRef] [PubMed]

3. Kopiasz, Ł.; Dziendzikowska, K.; Gajewska, M.; Oczkowski, M.; Majchrzak-Kuligowska, K.; Królikowski, T.; GromadzkaOstrowska, J. Effects of Dietary Oat Beta-Glucans on Colon Apoptosis and Autophagy through TLRs and Dectin-1 Signaling Pathways-Crohn's Disease Model Study. Nutrients 2021, 13, 321. [CrossRef] [PubMed]

4. Wolever, T.M.S.; Rahn, M.; Dioum, E.H.; Jenkins, A.L.; Ezatagha, A.; Campbell, J.E.; Chu, Y. Effect of Oat $\beta$-Glucan on Affective and Physical Feeling States in Healthy Adults: Evidence for Reduced Headache, Fatigue, Anxiety and Limb/Joint Pains. Nutrients 2021, 13, 1534. [CrossRef] [PubMed]

5. Gudej, S.; Filip, R.; Harasym, J.; Wilczak, J.; Dziendzikowska, K.; Oczkowski, M.; Jałosińska, M.; Juszczak, M.; Lange, E.; Gromadzka-Ostrowska, J. Clinical Outcomes after Oat Beta-Glucans Dietary Treatment in Gastritis Patients. Nutrients 2021, 13, 2791. [CrossRef] [PubMed]

6. Mio, K.; Yamanaka, C.; Matsuoka, T.; Kobayashi, T.; Aoe, S. Effects of Beta-Glucan Rich Barley Flour on Glucose and Lipid Metabolism in the Ileum, Liver, and Adipose Tissues of High-Fat Diet Induced-Obesity Model Male Mice Analyzed by DNA Microarray. Nutrients 2020, 12, 3546. [CrossRef] [PubMed]

7. Suzuki, S.; Aoe, S. High $\beta$-Glucan Barley Supplementation Improves Glucose Tolerance by Increasing GLP-1 Secretion in Diet-Induced Obesity Mice. Nutrients 2021, 13, 527. [CrossRef] [PubMed]

8. Mio, K.; Ootake, N.; Nakashima, S.; Matsuoka, T.; Aoe, S. Ingestion of High $\beta$-Glucan Barley Flour Enhances the Intestinal Immune System of Diet-Induced Obese Mice by Prebiotic Effects. Nutrients 2021, 13, 907. [CrossRef] [PubMed]

9. Aoe, S.; Mio, K.; Yamanaka, C.; Kuge, T. Low Molecular Weight Barley $\beta$-Glucan Affects Glucose and Lipid Metabolism by Prebiotic Effects. Nutrients 2021, 13, 130. [CrossRef] [PubMed]

10. Hughes, J.; Grafenauer, S. Oat and Barley in the Food Supply and Use of Beta Glucan Health Claims. Nutrients 2021, 13, 2556. [CrossRef] [PubMed]

11. Yasuda, K.; Nakashima, A.; Murata, A.; Suzuki, K.; Adachi, T. Euglena Gracilis and $\beta$-Glucan Paramylon Induce Ca ${ }^{2+}$ Signaling in Intestinal Tract Epithelial, Immune, and Neural Cells. Nutrients 2020, 12, 2293. [CrossRef] [PubMed]

12. Aoe, S.; Yamanaka, C.; Mio, K. Microarray Analysis of Paramylon, Isolated from Euglena Gracilis EOD-1, and Its Effects on Lipid Metabolism in the Ileum and Liver in Diet-Induced Obese Mice. Nutrients 2021, 13, 3406. [CrossRef] [PubMed] 